Portland State University

PDXScholar

Engineering and Technology Management

Student Projects

Fall 2012

\title{
Technology Assessment and Attractive Analysis of a New Concrete Modifier
}

\author{
Asem Alluhibi \\ Portland State University \\ Farshad Madani \\ Portland State University \\ Pinprapa Pakdeekasem \\ Portland State University
}

Follow this and additional works at: https://pdxscholar.library.pdx.edu/etm_studentprojects

Part of the Strategic Management Policy Commons, and the Technology and Innovation Commons Let us know how access to this document benefits you.

\section{Citation Details}

Alluhibi, Asem; Madani, Farshad; and Pakdeekasem, Pinprapa, "Technology Assessment and Attractive Analysis of a New Concrete Modifier" (2012). Engineering and Technology Management Student Projects. 7.

https://pdxscholar.library.pdx.edu/etm_studentprojects/7

This Project is brought to you for free and open access. It has been accepted for inclusion in Engineering and Technology Management Student Projects by an authorized administrator of PDXScholar. Please contact us if we can make this document more accessible: pdxscholar@pdx.edu. 


\section{ETM}

ENGINEERING \& TECHNOLOGY MANAGEMENT

\section{Technology Assessment and}

\section{Attractive Analysis of}

\section{a New Concrete Modifier}

Course Title: Technology Assessment and Acquisition (531/631)

Instructor: Dr. Daim

Fall, 2012

Author(s):

Asem Alluhib,

Farshad Madani,

Pinprapa Pakdeekasem , 


\section{Table of Contents}

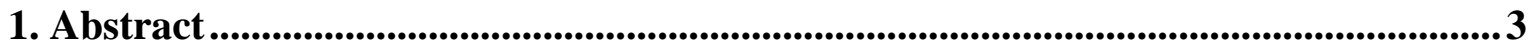

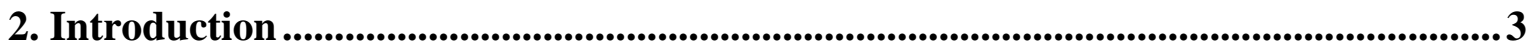

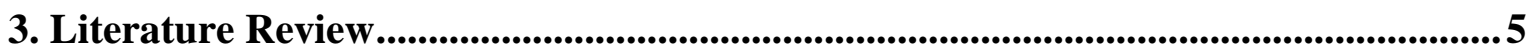

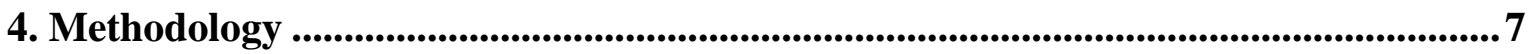

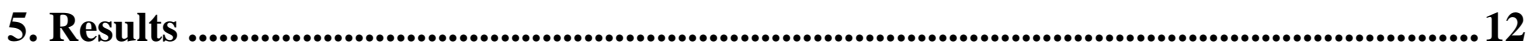

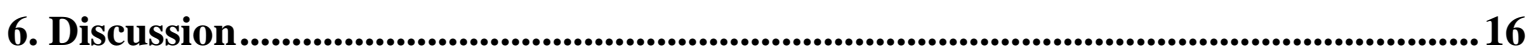

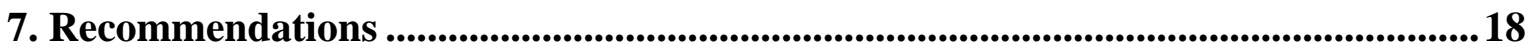

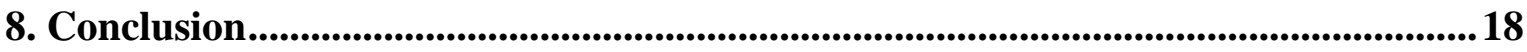

Bibliography ...............................................................................................................................................19

Appendix 1: Attractive Analysis Results...............................................................................20 


\section{$\underline{\text { 1. Abstract }}$}

MB, a new concrete modifier containing Silica Fume (FS), has fantastic performance based on the claims of a Russian Company. Iran's government decided to invest to produce this new concrete modifier. Iran concrete Institute (ICI) is dedicated to do this task. Technology assessment (TA), attractiveness analysis (AA), and business modeling are three main phases to study this investment. Applying TA and AA helps decision makers to make their mind based on technological facts and realities of the market. This paper covers the results of phases 1 and 2. At the end, MB is introduced a superior technology and appropriate strategies to enter the market and acquire the technology are proposed.

\section{$\underline{\text { 2. Introduction }}$}

Concrete has been used as the main material in construction due to its availability, cheap and risk free. Concrete performance is the main issue in construction industries, particularly in countries with special climate in some regions. For example, the Persian Gulf in the south of Iran has lots of Chlorine ions deteriorating concrete structures near to the Gulf. Moreover, many countries have the same problem such as Jamaica, South Africa, and other Middle Eastern countries around the Persian Gulf. Because of using low-quality of cement, these countries are substantially risky with the collapse from concrete destruction [1]. The Persian Gulf region is one of the most corrosive and aggressive marine environment for concrete. The severe corrosive problem is caused by low quality concrete, geographic problems as well as the lack of maintenance, workers' skills and knowledge about concrete construction. Consequently, reinforcement corrosion affects the overall economy of the Persian Gulf States. The geographic specification of the Persian Gulf region affects the durability of reinforced concrete structures because of high chloride ions and high temperature condition in marine environment. There are some solutions that can be used in order to prevent the corrosion issues. For example, using epoxy resins to cover piles is one of procedures to prevent the corrosion. Especially in tidal zone, epoxy resins will protect the piles from connection seawater and concrete layer. Another way is using cathodic protection; however, material is very expensive. Because of disadvantage of this method, the constructor should improve the quality of material and concrete contracture [2,3].

According to the serious issues made by corrosion and the volume of investments in industries, especially petrochemical and oil industries, around the Persian Gulf, Iran government is studying an offer from a Russian research institute. The offer contains 
producing a new concrete modifier, Master Beton (MB), with high performance, which can be a potential solution. To manage the studying, Iranian Concrete Institute (ICI) is designated by the government. The members of steering committee made by ICI are experts from Amir Kabir of Technology University (ATU) and the main investor, Mine and Industry Bank (MIB).

Master Beton (MB) is a concrete modifier for high performance concrete with high corrosion resistance. $\mathrm{MB}$ is the product from Russian company names Mater Beton Enterprise. MB is powder made from mineral and organic materials which are micro silica, fly ash and super plasticizer. The main component of MB is Silica Fume (SF), an amorphous (non-crystalline) polymorph of silicon dioxide and silica, which is really important for admixture material for high performance concrete. MB has a special characteristic of strong corrosion resistance in long term which suitable for alternative admixture to enhance concrete performance. Also, the exposed component of MB does not affect the environment. MB has been highly recommended to concrete industry with several reasons. For example, the unique of characteristics provide low permeability, high corrosion resistance, workable and durability, frost resistance along with high strength characteristic. Moreover, MB can be used directly during mixing without extra other mixture, but other admixture needs extra facilities in shop to be mixed in several phases. Also, MB's mixing time is shorter than other admixture, only 120 minutes. Another advantage of $\mathrm{MB}$ has a variety of functional application. MB can be used under many conditions such as underground and hydro-technical structure, laying protection coats of high density, extra-low permeability for preservation and dumping of waste including radioactive product and so on. Most importantly, cost of MB is less than other candidates. Thus, the attractiveness of this technology has drawn a lot of attraction from the investors. Moreover, MB seems to be the optimize alternative in order to solve a serious corrosive issue in Iran [4].

Other technology candidates also have component families of concrete with micro silicone base which are durable in corrosive environments. The next section illustrates the possible by-products from the considered technologies. Our list is based on corrosion resistance criteria which are our significant goal to improve the concrete construction in Iran.

Mapefluid: Mapefluid is super plasticizer liquid admixture for top quality concrete. It made from a formaldehyde-free $30 \%$ water solution of active polymers. It is suitable for watertight concrete, concrete for prefabricated structures, ready-mixed high performance concrete. It is complicate when using the Mapefluid during mixing process because it needs 
to be applied with other mixture. The advantages of Mapefluid are durable, high-performance concrete, to reduce thermal stress. It has negative impact to environment $[5,6]$.

Sikacrete: Sikacrete is a concrete admixture formulated to protect embedded reinforcing steel from corrosion. It made of Calcium nitrite-based admixture. It helps to reinforced concrete structures extends life of reinforced concrete structures. It is suitable for concrete that ready for mix applications. It also has neutral impact to the environment [7].

Seko Microdens: Seka dense is concrete admixture that helps to extend workability without the addition of extra water. It can be used with all types of Portland cements. Advantages of Seka dense are increasing strength compressive, flexural and bond of concrete to steel, reducing water content, reducing segregation. Seka Microdense has characteristics for flatwork and cast surfaces. Its application is not for using with the concrete which has not been mixed sufficiently. The drawbacks are expensive and negative impact to environment $[8]$.

\section{Literature Review}

Nowadays, emerging technology has a significant impact on high-tech industry. The intelligences of it and advance technology have brought a variety of assessing application. In order to maintain the competitive advantage, company needs to increase the effectiveness of performance in business by acquiring the appropriate technology to support its capabilities. In fact, the ability to be sustainable in market for the long-term has played an important role in the real business's world. Selecting the technology evaluation by using technology assessment reflects various perspectives to fulfill company's need. Technology assessment is one of aspect of the technology acquisition process. Adopting this tool will help company to optimize the most effective performance and balance the existing resource at the same time. The framework of assessment technology consists of three important perspectives; technical, organizational and personal. The implementation of technology acquisition will drive the capability in order to improve performance and long-term competitiveness.

Analytical Hierarchical Decision Model or HDM is a decision model for selecting the best alternative to pursue the most efficiency performance by using pair-wise comparison to measure the preference or the importance of criterion on another criterion. The score candidate technology comes from the judgment of expert panels. The experts are requested to evaluate each pair of candidate technology through the selected criteria. 
According to rapid increasingly competition in market, many companies are searching for special technique, which could enhance their competitive and advantages for long-term. In fact, investment in high-technology industry is one of the most sophisticate concerns for investors. There is slightly chance that shows risky in significant investment. In order to decrease the risk of investment, investors need to inspect the detail of particular business and attractiveness of investment as well. Recently some researched have been accomplished by applying business concepts and theories in technology management area to enrich rechnology assessment method. For example OECD reports [9] a study trying to increase attractiveness of international investments. In another research [11], technological attractiveness is evaluated by applying market factors. Through the structure of porter's model, it provides a framework for industry analysis along with business strategy by looking at five forces analysis. The five categories are threat of new entrants, threat of substitute of admixture product, suppliers, government impact, power of customers and exit barriers. The outcome from the analysis will declare the feasibility of business, the possibility for being sustainable in business and strategies for overcome the obstacles.

The investors need to evaluate the result from the attractiveness analysis whether they should invest or not. International investment has been used the attractiveness analysis for evaluating the feasibility of investment. In order to fulfill market needs with new technology, technology attractiveness has been applied for addressing strategic planning. In fact, the distinct benefit of this methodology draws a lot of attractiveness to R\&D developer [9].

One of the research papers used this application in order to find development of marketoriented R\&D planning. Researchers integrated the market portfolio concept with a patent portfolio in order to capture technological aspects. By combining market and technological analysis would show the needs in market and technology position. As a result, company managers were clarified on concern areas because they gained understanding of marketing and R\&D strategy. Therefore, market and technological analysis can support market-oriented R\&D planning [10].

Another evidence of applying attractiveness analysis in technology management area is the research studying technology assessment between China and Europe. The research perceived level of competitiveness attractiveness of each technology portfolio. From the international business study, the analysis of attractiveness assessments showed that Chinese and European were relies on different criteria. It also revealed that Chinese companies had lower performance compared to European companies because of lacking technological resources [11]. 


\section{Methodology}

As mentioned before, this research is a part of a larger project which has three main phases to convince investors to invest their money in MB production. So the methodology applied is the resultant of the requirements of the parental project and the wants of the course. The main project contains three phases including:

1- Technology assessment

2- Attractiveness analysis

3- Business Modeling

As shown in Table 1, all main concerns in technical, organizational, and personal perspectives are covered in three phases. Phase 1, technology assessment, focuses on factors affecting in comparing MB with other candidates. This phase helps investors to understand how much MB would be preferable to other candidates. Phase 2, attractiveness analysis, concentrates on competitive factors, based on Porter's Model. According to attractiveness analysis, investors can perceive current and future concerns in the industry and can pursue offered strategies to find a sustainable position. At the end to setup the business, if phase 2 proved $\mathrm{MB}$ is attractive enough to invest, in phase 3 all plans comprising marketing, production, supply, and financial plans as well as organizational model will be developed elaborately.

This research is restricted to phases 1 and 2. Phase 3 will be continued based on the results of this research. The main presumed policy dictated by the steering committee is that commencing each phase is depended on the result of prior phase. For example, if the results of tests in phase 1 did not prove Russian Company's claims, phase 2 would not get started. And if the results of phase 2 shows that the product is not assessed dominant in comparison to other technology candidates and the market wan not attractive to invest, phase 3 would not get commenced. In continue, methodologies applied in this research, phases 1 and 2, will be discussed.

\subsection{Technology Assessment}

To assess MB as a new technology, three modifiers, with close characteristics to MB, containing Seko Microdense, Mapefuid, and Sikacrete, were chosen by the steering committee; four goals including performance, cost, ease of use, and environmental impacts were selected as bases for hierarchical decision model (HDM) shown in figure Figure 1. 


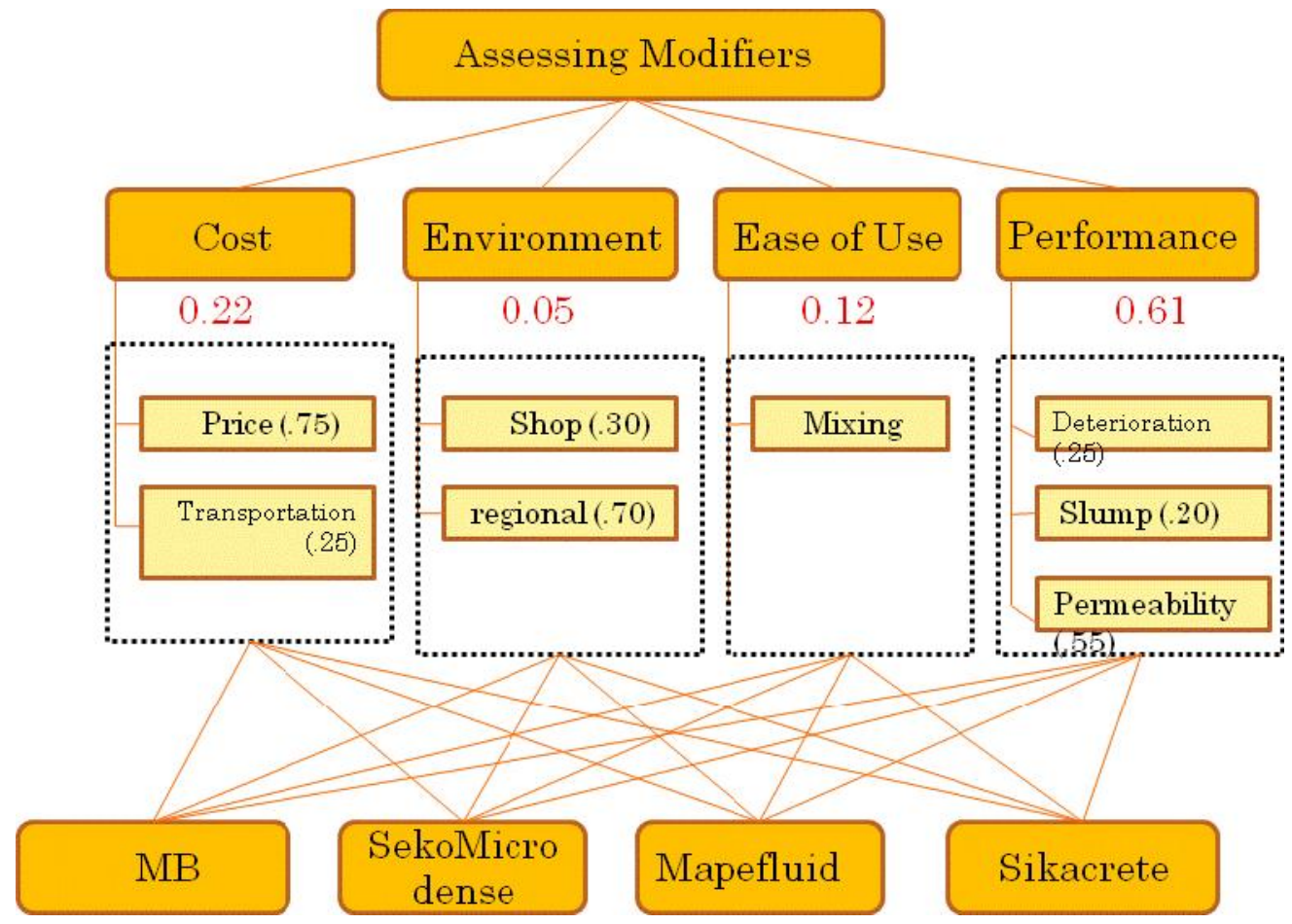

Figure 1- Applied HDM model in the case

According to "performance", and "environmental impact" criteria, all main necessary tests accomplished by Civil Engineering Department of Amir Kabir University of Technology (AUT). The result of three main tests including measuring deterioration, slump, and permeability against air, water, and Chlorine are selected among numerous technical tests done in AUT. Moreover, to judge about "ease of use", information about curing time in catalogues of modifiers are based.

Questionnaire was deployed as a main tool in phase 1 to gather experts' opinions regarding to their judgment about each criterion and the importance of each, the weights. So related data and information regarding to criteria were explained in a separate document to help experts answer questions and assess criteria. Except "price", all of the other criteria were quantified based on experts' judgment. To normalize "price" to be applicable in HDM model, the following formula is used:

$P N i=\frac{P i-P m i n}{P m a x-P m i n}$ Where Pi and PNi are the price and the normalized price of candidate i; Pmin and Pmax are the minimum, and the maximum prices of the candidates. 


\begin{tabular}{|c|c|c|c|c|}
\hline \multirow{2}{*}{ Phase } & \multicolumn{3}{|c|}{ Perspectives } & \multirow{2}{*}{ Outcomes } \\
\hline & Technical & Organizational & Personal & \\
\hline 1: Technology Assessment & $\begin{array}{l}\text { Performance: } \\
\text { - Deterioration rate } \\
\text { - Slump } \\
\text { - Permeability }\end{array}$ & $\begin{array}{l}\text { Cost: } \\
\text { - Price } \\
\text {-Transportation Cost }\end{array}$ & $\begin{array}{l}\text { Environmental Impacts: } \\
\text { - Shop } \\
\text { - Region } \\
\underline{\text { Ease of Use }} \\
\text { - Mixing }\end{array}$ & $\begin{array}{l}\text { - Technical Test Results } \\
\text { - Technology Assessment }\end{array}$ \\
\hline 2: Attractiveness Analysis & ---- & $\begin{array}{l}\text { Competitiveness } \\
\text { - Customers } \\
\text { - Suppliers } \\
\text { - Competitors \& Substitutes } \\
\text { - Entrant \& Exit Barriers } \\
\text { - Government's Effects }\end{array}$ & ---- & - Attractiveness Analysis \\
\hline 3: Business Modeling & $\begin{array}{l}\text { Production } \\
\text { Technology }\end{array}$ & $\begin{array}{l}\text { Business Model: } \\
\text { - Marketing Plan } \\
\text { - Production Plan } \\
\text { - Supply Plan } \\
\text { - Financial Plan }\end{array}$ & Organizational Model & - Business Plan \\
\hline
\end{tabular}

Table 1- Perspectives and outcomes of the main project 


\subsection{Attractiveness Analysis}

Although understanding the advantages and weaknesses of $\mathrm{MB}$ in comparison to the candidates is very important for every investor, it is not enough. Investors need business analysis as well as technology assessment analysis to make a reliable decision. To acquire analytical information regarding to modifiers business market, Porter's Model, renowned "five force", is applied. All factors elicited from Porter's Model are shown in table Table 2. To collect expert's judgment, a questionnaire is designed. A sample question is shown in Figure 2. Twenty five experts from governmental institutes and academia participated in the survey.

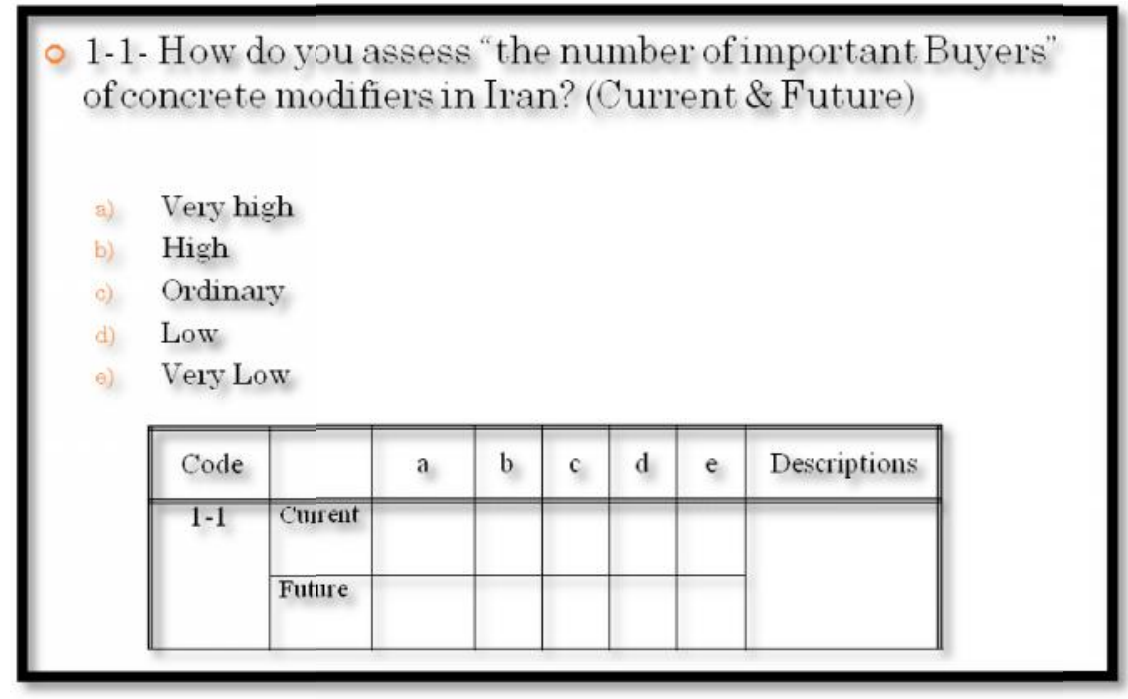

Figure 2- Sample question of attractiveness analysis questionnaire

As it's shown in Figure 2, each factor is questioned for the current time and future time, 5 years later, separately. Also Likert scale is applied which the answers are quantified as below: very high $=5$, high $=4$, ordinary $=3$, low $=2$, very low $=1$.

Moreover, to have a deep understanding of responses, the questionnaire have been filled out in a semi-structures interview meeting so that interviewer has explained each question and then interviewee has explained his reasons and at the end has filled out his response. This method enabled the research group to analyze profoundly the market in current and future time. Therefore, the team project could develop appropriate strategies offering investors how they can find a sustainable position in the market during and after their investment. 


\begin{tabular}{|c|c|}
\hline Part & Factors \\
\hline 1. Buyers & $\begin{array}{l}\text { - } \\
\text { - } \\
\text { - } \\
\text { - Bumbailability of substitutes of the industry } \\
\text { - Buyers' threat of backward integration } \\
\text { - Contribution to quality or service of buyers' products } \\
\text { - Total Buyers' cost contributed by the industry } \\
\text { - Buyer's Profitability }\end{array}$ \\
\hline 2. Suppliers & 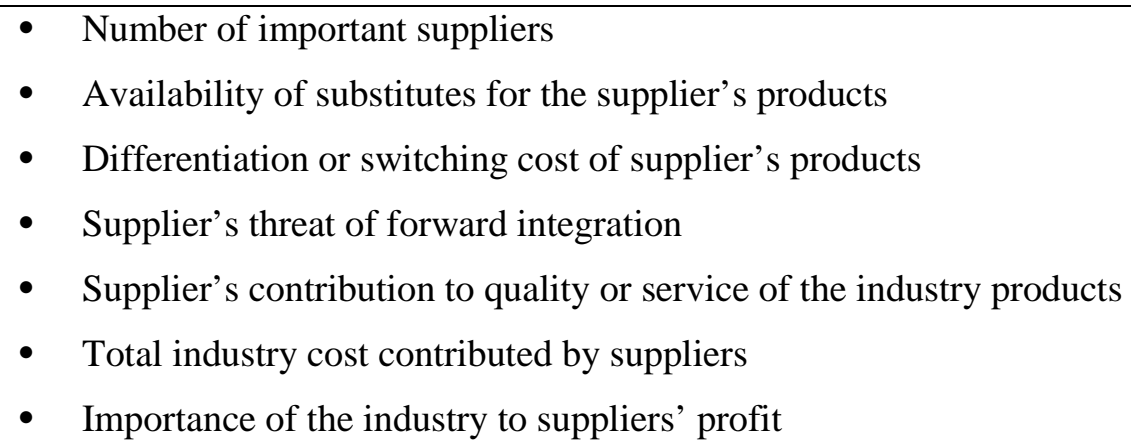 \\
\hline $\begin{array}{l}\text { 3. Competitor and } \\
\text { Substitute } \\
\text { Products }\end{array}$ & $\begin{array}{ll}\text { - } & \text { Industry Growth } \\
\text { - } & \text { Fixed (storage) Cost } \\
\text { - } & \text { Number of equally balanced competitors } \\
\text { - } & \text { Product Differentiation } \\
\text { - } & \text { Availability for close substitutes } \\
\text { - } & \text { Substitute producer's profitability and aggressiveness } \\
\text { - } & \text { Substitute Price-Value }\end{array}$ \\
\hline $\begin{array}{l}\text { 4. Enter \& Exit } \\
\text { Barriers and the } \\
\text { government }\end{array}$ & $\begin{array}{ll}\text { - } & \text { Economies of scale } \\
\text { - } & \text { Product Differentiation } \\
\text { - } & \text { Access to distribution Channel } \\
\text { - } & \text { Capital Requirement } \\
\text { - } & \text { Access to (latest) technology } \\
\text { - } & \text { Access to raw materials } \\
\text { - } & \text { Government Protection } \\
\text { - } & \text { Asset specialization } \\
\text { - } & \text { Strategic interrelationship } \\
\text { - } & \text { Government and social restrictions } \\
\text { - } & \text { Industry Protection } \\
\text { - } & \text { Industry Regulation } \\
\text { - } & \text { Custom duties }\end{array}$ \\
\hline
\end{tabular}

Table 2- Five Force's factors applied for attractiveness analysis 


\section{$\underline{\text { 5. Results }}$}

Gap analysis, applying HDM model in technology assessment, and attractiveness analysis are three main contributions which are explained in this section.

\subsection{Gap Analysis}

In order to achieve the goal for this project, gap analysis is prepared as it's shown in tableTable 3. Gap analysis is the base of extracting affecting factors that we need to consider in HDM model later. Therefore gab analysis helps decision makers to understand how applying MB can fill the gaps. To analyze gaps, the situation of current modifiers in the market is considered and compared with the desirable situation that future stakeholder want. The future stakeholders are different professions who will enjoy from MB's benefits. They are CEOs working in construction and consulting companies; they are engineers designing concrete structures; they are technicians working in construction shops; and they are people living or working in construction.

\begin{tabular}{|c|c|c|c|}
\hline Gap Analysis & Requirements & Capabilities & Gaps \\
\hline Technical & $\begin{array}{l}\text { - Minimal } \\
\text { environmental impact. } \\
\text { - Financial benefit in } \\
\text { long term. } \\
\text { - Need high } \\
\text { performance concrete }\end{array}$ & $\begin{array}{l}\text { - No need more mixing } \\
\text { facilities } \\
\text { - Applicable in different } \\
\text { environments } \\
\text { - Much more denser }\end{array}$ & $\begin{array}{l}\text { - Need mechanism to } \\
\text { make stable curing } \\
\text { time } \\
\text { - Modify concrete } \\
\text { properties against } \\
\text { harmful environment. }\end{array}$ \\
\hline Organizational & $\begin{array}{l}\text { - Less transportation } \\
\text { cost. } \\
\text { - Less capital } \\
\text { investment } \\
\text { - Less maintenance cost. }\end{array}$ & $\begin{array}{l}\text { - No need more mixing } \\
\text { facilities } \\
\text { - Much more denser } \\
\text { - Much more endurable }\end{array}$ & $\begin{array}{l}\text { - The density of } \\
\text { admixtures need to be } \\
\text { more }\end{array}$ \\
\hline Personal & $\begin{array}{l}\text { - Clean environment } \\
\text { - Safer construction } \\
\text { - Cheaper construction }\end{array}$ & $\begin{array}{l}\text { - Sustainability } \\
\text { - Ease of use }\end{array}$ & $\begin{array}{l}\text { - Finding more } \\
\text { endurable construction } \\
\text { - Making more } \\
\text { manageable mixing } \\
\text { process }\end{array}$ \\
\hline
\end{tabular}

Table 3- Gap Analysis in three perspectives

In technical perspective two main issues including environmental and performance are considered. The capabilities of current modifiers needed to be developed in order to meet the gaps. For example, MB is has solved the low density of SF so that construction companies can enjoy SF's benefits in different environment. Current modifiers have negative impacts on the environment in construction shops so that workers are harmed due to air pollution in the shops. Also SF is an air pollutant in regions where SF is produced so it's required to find an 
application for SF so that minimize environmental impact. In addition, having high performance concrete will lead to financial benefits in long term.

In organizational perspective, financial issues are mainly reflected. Less transportation and maintenance costs are required as well as considering less capital investment in construction project are concerns of CEOs and project managers. MB can potentially cover these gaps since it causes to super performance which leads to less maintenance cost, and it has solved the transportation cost of SF whose density is too low.

In personal perspective, environmental impact, safety, financial issues and ease of use are addressed as main concerns. People living around factories producing SF as a by-product suffer from pollutions made by it; finding applications for SF help them to have more sustainable environment. Also people living or working in constructions built by high performance concretes apparently will enjoy more safety in long time and even cheaper. Applying improved modifiers like MB will benefit technicians and workers to enjoy ease of use it since mixing process would become shorter and easier.

\subsection{Technology assessment}

HDM model is applied as main tool to process experts' opinions in a structured process. The HDM is constructed with four levels, objective, criteria, sub-criteria and candidates, figure Figure 1. The first level represents the main goal which is selecting the best candidate for the project. The second level contains the main criteria for choosing the best candidate. All of the criteria are goals that need to be met in order to fulfill the objective. The third level addresses sub criteria related to each of the criteria. The forth level represents the candidates including MB, Sika crete, Mapefluid, and Seco microdense.

The weight of criteria and sub criteria are assessed by using pairwise comparison in accordance with the relative impact of each criterion in the decision making process. In order to determine the final weights for each criterion, PCM software is employed to compare each criterion against the others and the results are shown in Figure 1. The weight are normalized between 0 and 1 .

The score of all sub criteria are calculated based on quantified expert's judgment between 1 and 5 and the weights which have calculated separately based on their pairwise comparison. The result is shown in Table 4. 


\begin{tabular}{|c|c|c|c|c|c|c|c|c|}
\hline \multirow[b]{2}{*}{ Candidate } & \multicolumn{2}{|c|}{ Cost } & \multirow{2}{*}{$\begin{array}{l}\text { Ease of } \\
\text { use }\end{array}$} & \multicolumn{2}{|c|}{$\begin{array}{l}\text { Environmental } \\
\text { Impaet }\end{array}$} & \multicolumn{3}{|c|}{ Performance } \\
\hline & Price & $\begin{array}{l}\text { Transpor } \\
\text { tation }\end{array}$ & & Regional & Shop & $\begin{array}{c}\text { Permeabilit } \\
y\end{array}$ & Slump & $\begin{array}{c}\text { Deteriorati } \\
\text { on }\end{array}$ \\
\hline MB & 4.7 & 3.7 & 4.4 & 4 & 3.7 & 4.6 & 4.4 & 4.7 \\
\hline $\begin{array}{c}\text { Seko } \\
\text { Microdense }\end{array}$ & 2.9 & 2.5 & 3.3 & 1 & 3 & 2.7 & 3 & 3.2 \\
\hline Mapefluid & 2.3 & 2.6 & 3.3 & 1 & 2.9 & 2.3 & 2.8 & 2.9 \\
\hline Sikacrete & 3.4 & 2.5 & 3.2 & 1 & 2.9 & 2.5 & 3.2 & 2.7 \\
\hline
\end{tabular}

Table 4- Calculated scores of the candidates

As it illustrated in Table 4, MB clearly has the highest scores. It costs 300\$/ton, which considers as the cheapest price among other candidates. Experts also gave a score of 4.7 and 3.7 out of 5 for the cost of the price and transportation respectively. Moreover, the use and flexibility of the additive material is very preferable comparing to others and has a score of 4.4. In addition, it has low negative impacts on the environment, which is one of the most vital requirements for the future state of the project. Environmental impacts is divided in two parts regional and shop and scored 4 and 3.7 respectively. Eventually, performance plays a big factor in choosing MB, and has three parts permeability, slump and deterioration, which scored 4.6,4.4 and 4.7 respectively. Thus, MB is the best fit candidate as the result of HDM for $\mathrm{MB}$ is $87.8 \%$ and is the highest comparing to other candidates, Table 5.

\begin{tabular}{|l|c|}
\hline \multicolumn{1}{|c|}{ Candidates } & Result \% \\
\hline MB & 87.8 \\
\hline Seko Microdense & 56.2 \\
\hline Sikaccrete & 54.1 \\
\hline Mapefluid & 51.7 \\
\hline
\end{tabular}

Table 5- final scores of technology assessment

\subsection{Attractiveness analysis}

In attractiveness analysis like technology assessment, the main tool for gathering experts' judgment is questionnaire. The results of each part are shown in appendix 1. The scores are between 1 and 5 based in Likert scale used in the questionnaire. Also, experts are asked for each question why they have chosen that option so that the team could extract the threats and opportunities based on their response. The threats and opportunities are shown in Table 6. 


\begin{tabular}{|c|c|c|}
\hline Porter's model elements & Opportunity & Threat \\
\hline New Entrants & $\begin{array}{l}\text { - Other competitors don't have } \\
\text { access to the source of } \\
\text { technology in short term. } \\
\text { - Access to raw materials is hard } \\
\text { for competitors. }\end{array}$ & $\begin{array}{l}\text { - Low investment. } \\
\text { - Low credibility of Russian } \\
\text { company in the market in } \\
\text { comparison to the brand of } \\
\text { Western competitors' } \\
\text { products. } \\
\text { - Availability of distribution } \\
\text { channels. }\end{array}$ \\
\hline Suppliers & $\begin{array}{l}\text { - Super plasticizer price } \\
\text { reduction. }\end{array}$ & $\begin{array}{l}\text { - The number of SF suppliers is } \\
\text { too low. } \\
\text { - Low profitability of SF for its } \\
\text { producers. } \\
\text { - Unreliable quality of SF. } \\
\text { - Unavailability of other } \\
\text { Pozzolan as substitutes in } \\
\text { short term. }\end{array}$ \\
\hline Competitors and Substitutes & $\begin{array}{l}\text { - High and reliable growth of the } \\
\text { market (additives and } \\
\text { modifiers). } \\
\text { - Huge gap between MB and its } \\
\text { competitors in terms of } \\
\text { performance and cost. } \\
\text { - }\end{array}$ & $\begin{array}{l}\text { - Emerging new technologies in } \\
\text { the future (close substitutes). }\end{array}$ \\
\hline Government Impacts & $\begin{array}{l}\text { - The government's supports for } \\
\text { MB's technology transfer. } \\
\text { - Issuing new imperative laws } \\
\text { about increasing the quality of } \\
\text { construction. } \\
\text { - Offered incentives by the } \\
\text { government to invest in less } \\
\text { developed regions. } \\
\text { - Tax exemption for industries } \\
\text { exporting their products }\end{array}$ & \\
\hline Customers & $\begin{array}{l}\text { - High potential demand ( } 8500 \\
\text { MB T/Year). } \\
\text { - Cost advantage in } \\
\text { international market. } \\
\text { - }\end{array}$ & $\begin{array}{l}\text { - Costumers' high sensitivity to } \\
\text { cost and quality and their } \\
\text { unfamiliarity with MB. }\end{array}$ \\
\hline Exit Barriers & - Flexible production machinery. & \\
\hline
\end{tabular}

Table 6- Opportunities and Threads of investment in MB 


\section{Discussion}

There are some important discussions around the methodology and the results derived in technology assessment and attractiveness analysis that they will be discussed in this section.

\section{Discussion 1- Methodology}

Decision making to invest in a new technology is a multidisciplinary process. However HDM modeling applied in technology assessment is a convenient tool for considering all related factors in decision making; decision makers need more profound information and analysis in some aspects like the market in this case. In some cases like this research, few decision makers (DMs) make their decisions based on a few experts' judgments so DMs need quantified judgments as well as reasons and explanations under quantifications. Therefore, applying HDM models might not be enough for decision making; to compensate this weakness, applying a complementary is required. Selecting the complementary method depends on the nature of the aspect that DMs need deeper information. In this case, since DMs need more information about attractiveness of the market to invest there, Porter's model is chosen to enable DMs to analyze MB competitiveness in the market.

\section{Discussion 2- Technology assessment}

As shown in Table 5, MB has dominant superiority on the other candidates. Although the performance of the other candidates is high since they are modifier like MB, the performance of MB is absolutely superior. The average score of experts' opinion in all of three main tests prove this superiority.

According to environmental impact, $\mathrm{MB}$ has better conditions to lessen air pollution in construction shops, based on experts' judgment. Also Producing MB would have a huge improvement in the air quality of the region where Silica Fume produces because the Ferro Alloy Company has not to bury SF in the ground and pollute the environment. This advantage is not applicable for the others candidate since they are mostly imported products and consequently don't have any environmentally regional impact.

In the case of "ease of use", since super plasticizer is in MB, it doesn't have troubles of the others'. MB can be mixed in a shorter time and it doesn't need extra facilities to be mixed with other admixtures.

The price of MB is one of his advantages so that it can have a good market in Middle East market. Also based on the experts' opinion its transportation cost is much less than the other 
candidates. The main reason is its high density and no need to more admixtures which means less transportation cost.

The final scores in this phase shows MB is an ideal modifier in terms of performance, cost, environmental impact, and ease of use, but the investors need more knowledge regard to the market to make their final decision which will be discussed in next section.

\section{Discussion 3- Attractiveness Analysis}

Attractiveness analysis results provide complementary information regard to the market which this information helps investors to make riper decision concerning how to acquire technology and how to enter into the market. All the opportunities and the threats elicited from attractiveness analysis are shown in table Table 6.

Generally, technology assessment and attractiveness analysis show MB has lots of advantages and opportunities in comparison to the other candidates. On the other hand, there are some threats in the market that the investors need to prime appropriate strategies to cope with them. The scores, shown in Figure 3, emphasizes that there are more serious problems in "suppliers" side and "barriers to enter".

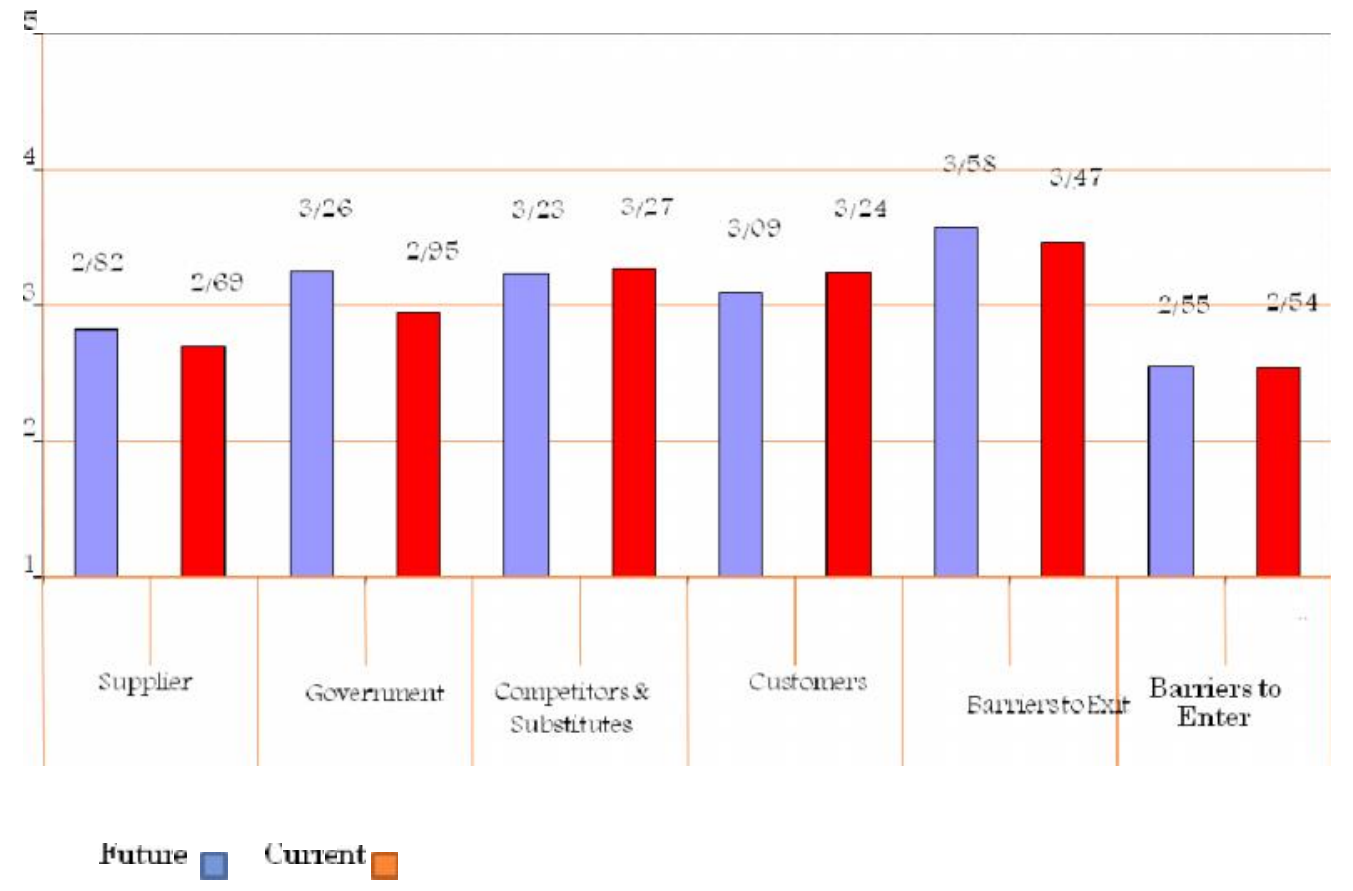

Figure 3- Attractiveness analysis scores 
To have reliable investment, it's recommended to investors to pursue the following strategies:

- Commencing promotional programs to increase the awareness of customers, and professional private and public companies and institutes

- Technology acquisition through In-house development. The studying shows the cost of in house development is $1 / 3$ the Russian Company's suggestion, turn-key. The Russian Company can participate in the project as a consultant.

- Partnering with one of big Ferro alloy companies (SF producers) can guarantee SF future supply. Also, investors can encourage the partner to improve its quality through this partnership.

\section{$\underline{\text { 7. Recommendation }}$}

Although the HDM model results shows that MB has a remarkable advantage on the other candidates, they cannot insure buyers' future behavior since all of the results are based on just 25 experts' judgments who are mostly from governmental agencies and academia. Furthermore, modifiers market is a fragmented market where lots of known brands exist and many options are available for buyers. Therefore, to compensate lack of data from customers' side, a market survey is needed to reflect all customers' views. Moreover, the variety of applications of modifiers like MB and complicated relationship between suppliers and construction companies necessitate studying professional players in the market as well.

\section{Conclusion}

Applying attractiveness analysis as well as technology assessment helps investors to make their final decision by considering both technological and market aspects. In this case, applying these two methods show that $\mathrm{MB}$ is comparatively better than the other candidates, but the attractiveness of investment on MB production is not enough high; it's medium. It means investment on MB is not potentially so attractive for investors. So to have a confident investment, and achieve a sustainable position, investors need to pursue some strategies to cope with the threats and to benefit from opportunities. The strategies are mainly regard to "product promotion", "technology acquisition", and "partnering". 


\section{References}

1. Jon Walton, April 2012. The World's Concrete Problem. [ONLINE] Available at: http://www.constructiondigital.com/under construction/the-worlds-concrete-problem

2. Mohammad Shekarchi and Farid Moradi, CBM-Cl International Workshop, Karachi, Pakistan. Concrete Durability in the Persian Gulf. [ONLINE] Available at: http://enpub.fulton.asu.edu/cement/cbm Cl/CBMI Separate Articles/Article-37.pdf

3. N. Arafati, N. Fazli, S. Mehdi Mousavi and F. Rouzmehr, 2012. Construction Research Congress 2012 @ ASCE 2012, Construction and maintenance of concrete piles in corrosive and destructive marine environments, based on study of the Persian Gulf marine installations. [ONLINE] Available at: http://rebar.ecn.purdue.edu/crc2012/papers/pdfs/37.pdf

4. Mater Beton Enterprise company. http://www.master-concrete.com/eng/modifiers.htm

5. SpecialChem, Jul 2011. Mapei's Concrete Admixtures Account for 30\% of UAE Construction Market. [ONLINE] Available at:

http://www.specialchem4adhesives.com/resources/latest/displaynews.aspx?id=5030

6. Mapei. Mapefluid PZ500 Superplasticiser for Concrete with Pozzolanicaction. [ONLINE] Available at:

http://down.archicentrum.hu/19/tadatlapok/mapefluidpz500.pdf?f \%5Bcegid\%5D=19

7. Sika company website. http://usa.sika.com

8. Iran Construction Clinic. http://www.clinic-iran.com/Content.aspx?sr=n\&ct=product\&cid=36

9. Organisation for Economic Co-operation and Development, 2011, Attractiveness for innovation: Location factors for international investment. Paris: OECD.Ernst, B. Fabry and J.

10. Henrik Soll, Enhancing market-oriented R\&D planning by integrated market and patent portfolios, Journal of Business Chemistry, Volume 1, Issue 1, May 2004, page 1-13.

11. D. Jolly, Chinese vs. European views regarding technology assessment: Convergent or divergent?, Technovation, Volume 28, Issue 12, December 2008, Pages 818-830. 
Appendix 1- Attractiveness analysis results

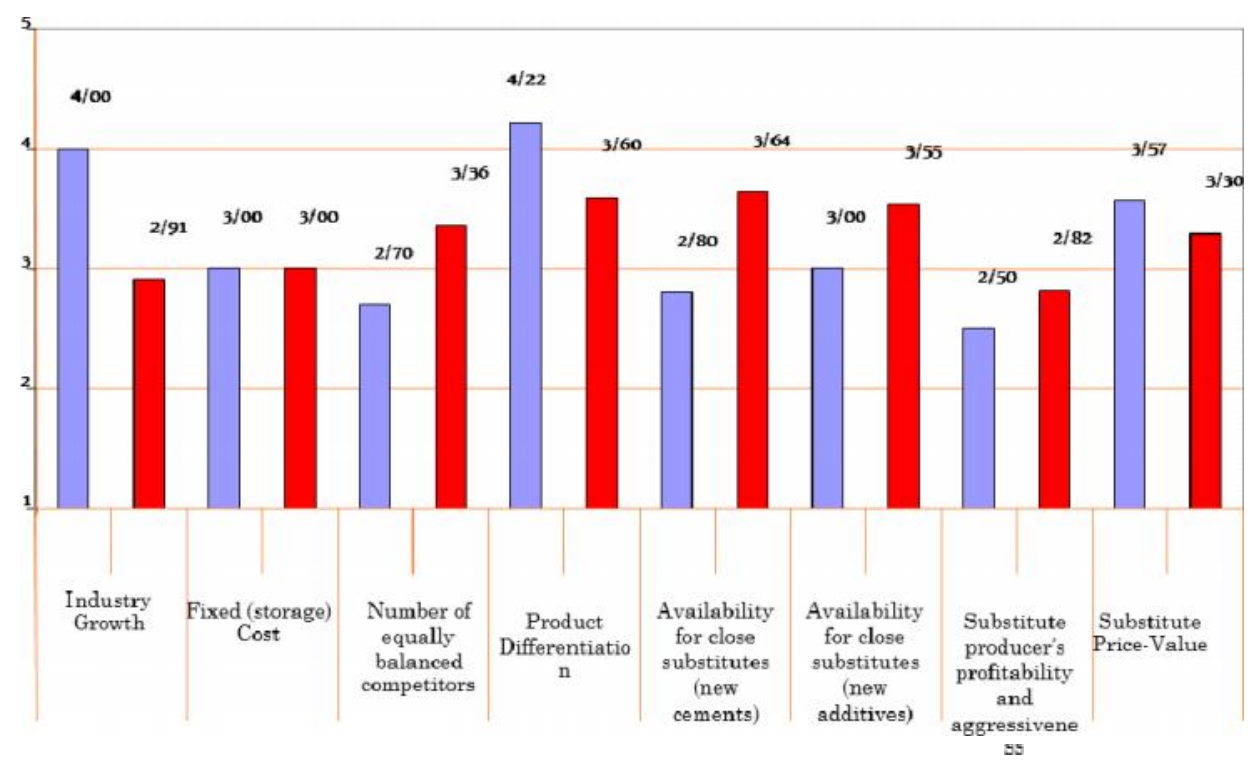

Future $\square \quad$ Current $\square$

Figure 4- Competitors and Substitutes

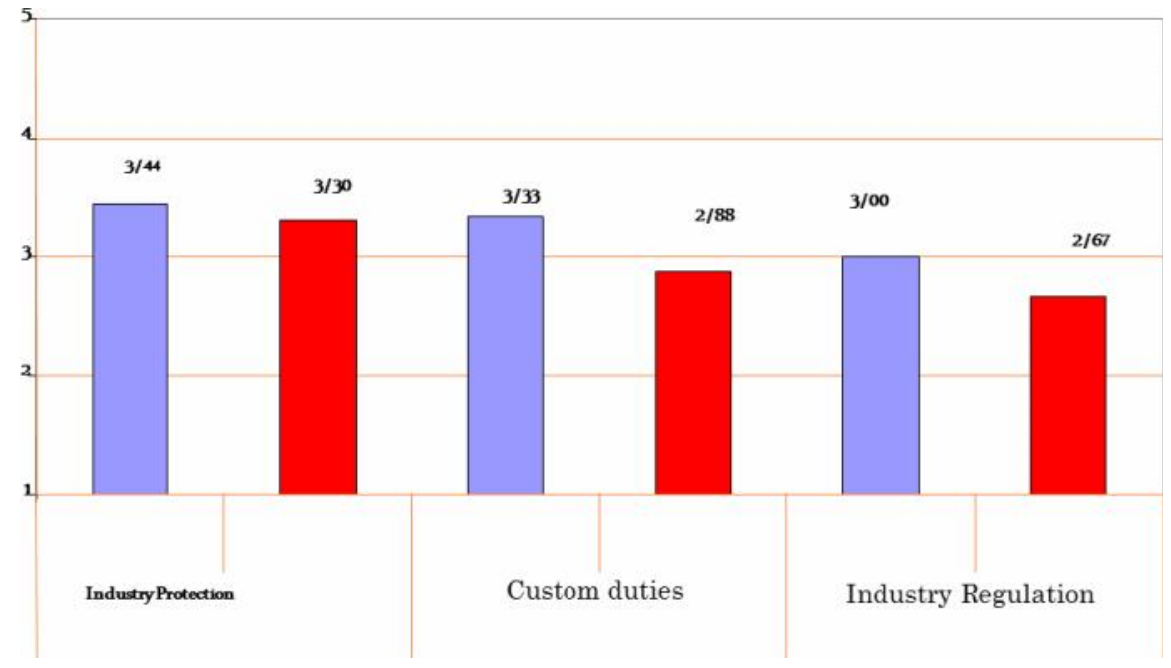

Future $\square \quad$ Current $\square$

Figure 5- Government 


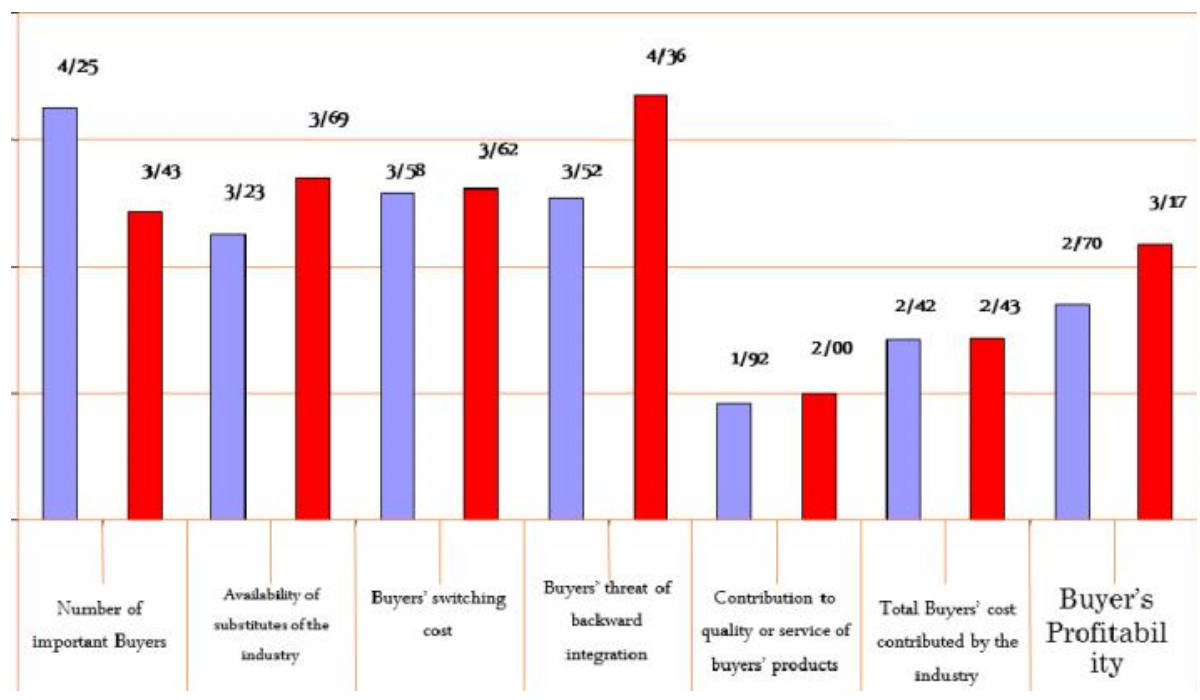

Future $\square \quad$ Current $\square$

Figure 6- Customers

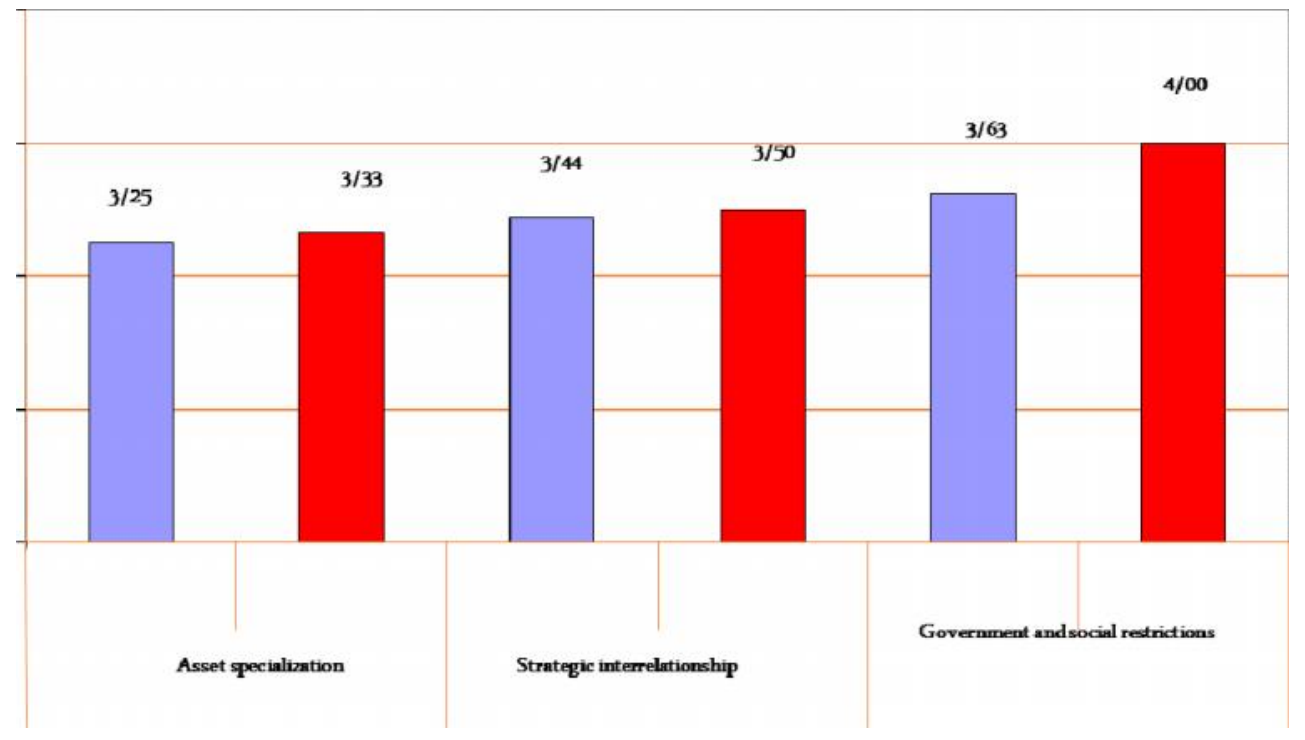

Future $\square \quad$ Current $\square$

Figure 7- Exit Barriers 


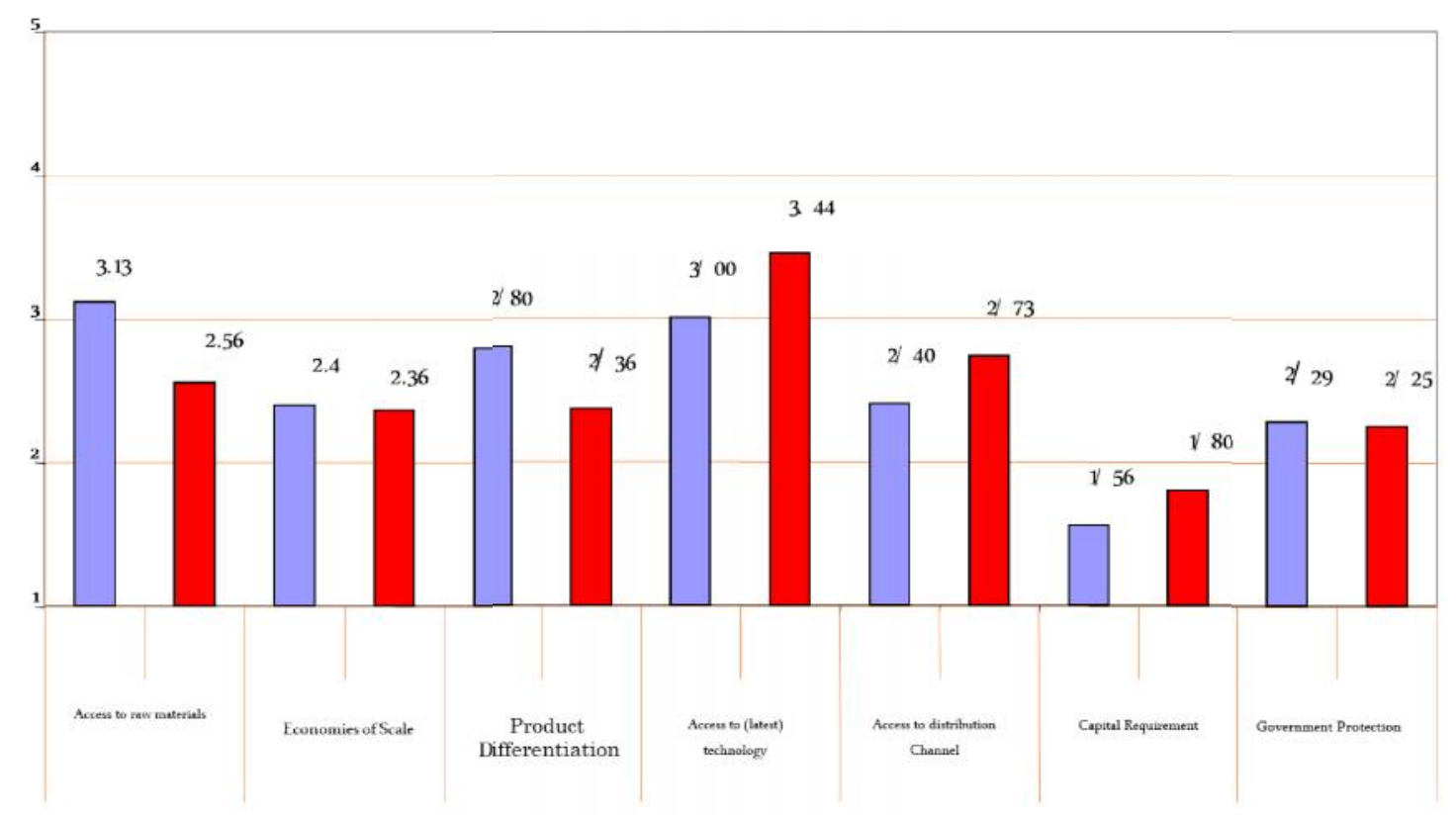

Future Durrent

Figure 8- New Entrants

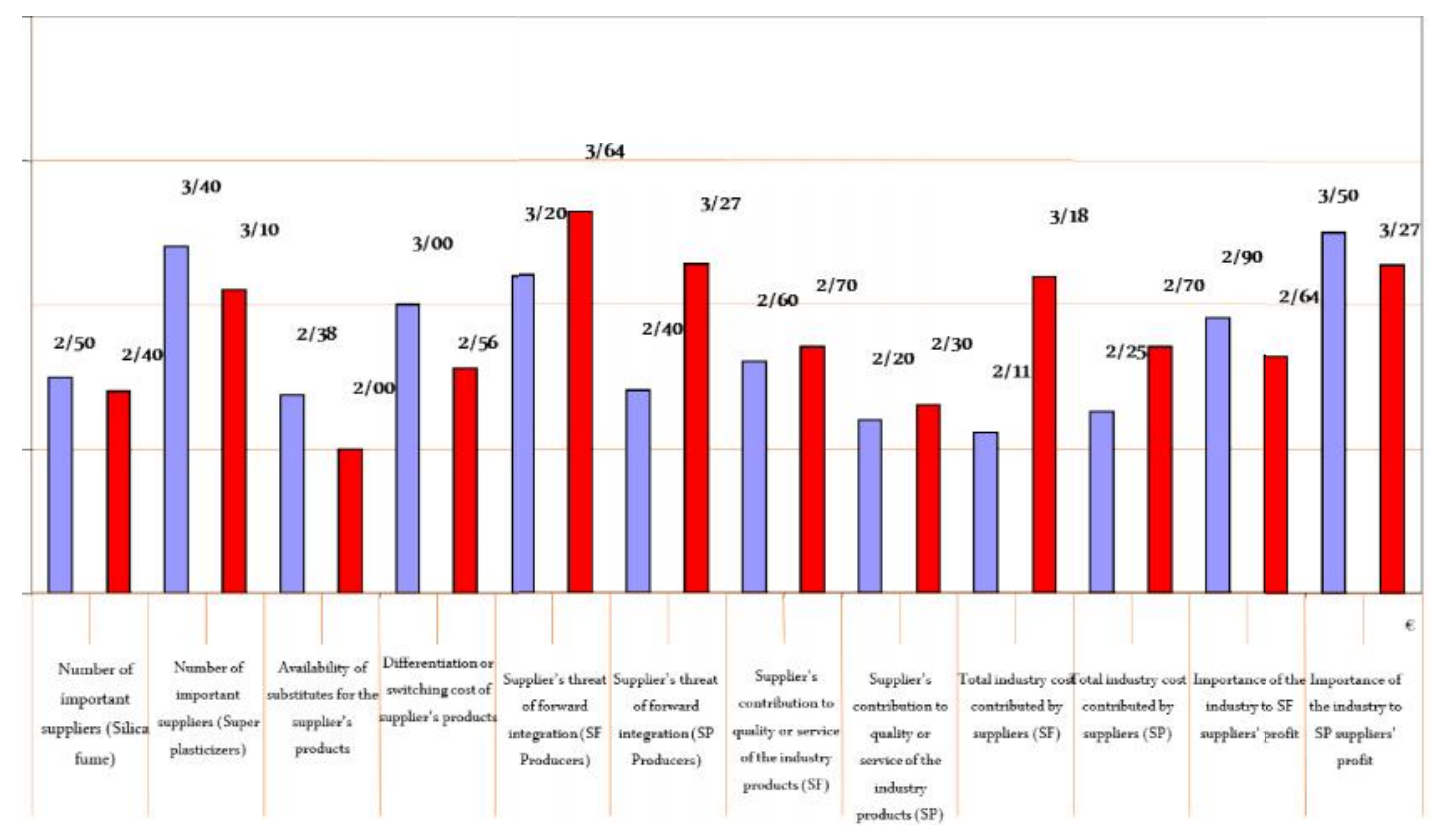

Future $\square \quad$ Current $\square$

Figure 9- Suppliers 